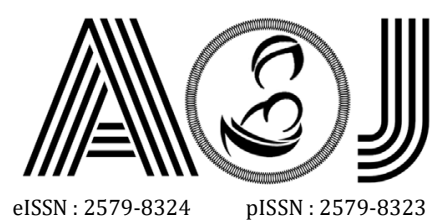

eISSN : 2579-8324
pISSN : 2579-8323

\title{
RESEARCH
}

\section{Differences of Misoprostol and Oxytocin Effect on Cervical}

\section{Ripening}

Imelda Yunitra ${ }^{1}$, Putri Sri Lasmini ${ }^{1}$, Hafni Bachtiar ${ }^{2}$

Affiliations : 1. Obstetrics and Gynecology Department, Faculty of Medicine, Andalas University, Dr. M. Djamil Central General Hospital Padang; 2. Public Health Department, Faculty of Medicine, Andalas University Padang

Correspondence: Imelda Yunitra, email : imeldayunitra@yahoo.com, Hp: 08129997941

\section{Abstract}

Many studies has been done to determine the effectiveness of misoprostol and oxytocin even comparing the use of them for the induction of labor. Based on those studies, there seems to be a different effect of misoprostol and oxytocin on different phase of parturition, start from cervical ripening, uterine contraction and successful labor. Compared to oxytocin as cervical ripening agent, misoprostol is more available, cheaper, and effective. This study was an experimental study using pre-post control group to evaluate the difference of misoprostol and oxytocin effect on cervical ripening. This study was conducted at RSUP DR. M. Djamil Padang and Secondary Hospital in periode of January-October 2014. Independent variable was cervical ripening using misoprostol $25 \mu \mathrm{g}$ and oxytocin drip. Dependent variables are the event of cervical ripening and the increase of Bishop score. The average of cervical ripening using misoprostol was higher than oxytocin with 7,0968 $\pm 2,11904$, compared to 2,5806 $\pm 3,36427$. This difference was significantly different with $p>0.05$. It can be concluded that misoprostol is a better cervical ripening agent than oxytocin. Oxytocin is better given to ripe cervix

Keywords: severe preeclampsia, folic acid, normal pregnancy

\section{INTRODUCTION}

Stimulation of uterine contractions and the use of cervical ripening are common actions in labor. According to recent studies, the rate varies between 9.5-33.7 percent of all pregnancies each year. National center for health statistics, the incidence of labor induction in America was $9.5 \%$ in 1991 and increased to $22.5 \%$ in 2006. ${ }^{1,2}$ At Dr.M Djamil Hospital in 2012, induction of labor was carried out in 85 patients with various indications .

The success of labor induction is related to the status of the cervix and oxytocin receptors. If there is an immature cervix, vaginal delivery has a little chance of success. Many studies have been carried out to assess the importance of cervical status before labor induction. Calkins et al in a systematic study of factors that affect the duration of $1^{\text {st }}$ phase of labor, states that the length, thickness and consistency of the cervix are important parameters. In 1964, Bishop assessed cervical scoring in women for planned labor induction, and Bishop's score became the pre-induction scoring used in general. If the cervix scores low, the rate of failure to induce labor will increase. According to research conducted by Friedman et al (quoted from Serudji J in 1993) on Bishop's value $\geq 9$, no labor induction failure was 


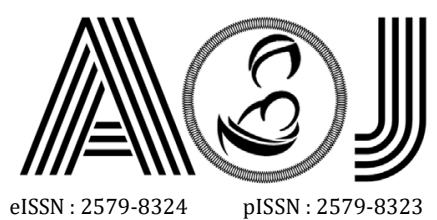

eISSN : 2579-8324
pISSN : 2579-8323

Ruang Redaksi Andalas Obstetrics and Gynecology Journal, Lantai 3 PPDS Obstetri dan Ginekologi Universitas Andalas, RSUP DR. M. Djamil Padang, Jl. Perintis Kemerdekaan Padang, Sumatera Barat 25127

Website:

http://jurnalobgin.fk.unand.ac.id/index.php/JOE

found, on the contrary the Bishop value between 5 - 8 obtained $4.8 \%$ failure and at Bishop 0 - 4 failures at $19.5 \%$. Several studies have found that cervical ripening before labor induction significantly reduces the incidence of caesarean section from $21 \%-30 \%$ to $3 \%-16 \%{ }^{3}$ Therefore a cervical ripening agent is needed to ripen the cervix before labor induction. $1,3,4,5$

Various studies have been conducted to assess the effectiveness of misoprostol and oxytocin, even some studies comparing the use of misoprostol and oxytocin as induction of labor.

\section{METHOD}

This study was an experimental pre-post control group design study to assess the proportion of the different effects of misoprostol and oxytocin on cervical ripening.

The study was conducted at Dr.M.Djamil Hospital in Padang and the network hospital. The study period began in January 2014 until October 2014. The independent variable was cervical ripening using $25 \mu \mathrm{g}$ misoprostol and oxytocin drip. The dependent variable is whether or not cervical ripening occurs and the assessment of Bishop score increases.

Sampling was done by consecutive sampling on Obstetrics and Gynecology patients in Dr.M.Djamil Hospital and network hospitals that met the inclusion criteria until the number of samples were met.

Bishop score assessment is done to assess cervical maturity, assessment is done by deep examination, conducted by researchers then recorded on the protocol form paper. The next examination is an examination to determine whether the patient is in labor or not, by assessing the RPM test, by asking the mother to twist her nipples for 10 minutes then assessing uterine contractions with CTG. If the RPM test results are negative then the patient meets the inclusion criteria.

The bishop score was assessed within 24 hours of drug administration, the assessment of each sample group was carried out by the time at 6,12,18, and 24 hour. The assessment of the Bishop value, cervical ripening was considered successful if the bishop value was $\geq 5$, or cervical dilatation $\geq 3 \mathrm{~cm}$, or labor has entered the active phase, labor management in accordance with partograph. If there are side effects from drug administration, drug administration is stopped and treatment of complications is given. If after 24 hours of drug administration, there is no change in bishop score or labor does not enter the active phase then cervical ripening is unsuccess.

\section{RESULT \& DISCUSSION}

During the study period, the number of aterm pregnant patients with termination of pregnancy that met the inclusion criteria and did not meet the exclusion criteria included in 


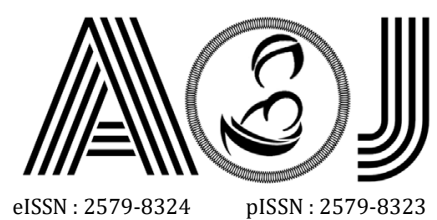

eISSN : 2579-8324
pISSN : 2579-8323
ANDALAS OBSTETRICS AND GYNECOLOGY JOURNAL

Alamat Korespondensi:

Ruang Redaksi Andalas Obstetrics and Gynecology Journal, Lantai 3 PPDS Obstetri dan Ginekologi Universitas Andalas, RSUP DR. M. Djamil Padang, Jl. Perintis Kemerdekaan Padang, Sumatera Barat 25127

Website:

http://jurnalobgin.fk.unand.ac.id/index.php/JOE

Dr.M.Djamil Padang Hospital was 62 cases, with 31 patients for each group. Misoprostol is given vaginally at a dose of $25 \mu \mathrm{g}$ and oxytocin is given by induction drip.

The results of this study illustrate that the effect of misoprostol on cervical ripening is better than the effect of oxytocin. Assessments carried out in 24 hours, on the ripening of the cervix with misoprostol, $90.3 \%$ success was achieved, while on cervical ripening with oxytocin, $32.2 \%$ success was obtained. In this study, the most comparable increase in cervical changes was in the second administration, which was at 6 hours. In the administration of misoprostol an increase in bishop score of $96.7 \%$, with a ripened cervix $41.9 \%$. In oxytocin an increase in cervical bishop score only occurred $32.3 \%$ with cervical ripening of $19.3 \%$. The increase in bishop score was also different in the two groups, in cervical ripening using misoprostol there was an increase in score at most 2 points with a frequency of 13 samples and the highest increase in bishop score was 6 points. Cervical ripening with oxytocin which increase in bishop scores was 9 patients; 3 patients each on 1 score, 3 scores and 4 scores. Changes in the cervix with bishop score assessment at 6 hours of administration up to 24 hours of administration obtained a significant difference between misoprostol and oxytocin. This can be explained that prostaglandins have uterotonin and uterotropin properties. As uterotonin, prostaglandin causes uterine contractions in all pregnancies. ${ }^{2,6}$ It also appeared that oxytocin was uterotonin only, so it took longer to achieve cervical dilatation.

Based on statistics, the changes in cervix that were shown in this study were seen in the bishop assessment scores which increased at 6 hours of administration. On misoprostol administration, there was a significant change in the improvement of bishop score compared to oxytocin. In the second administration, i.e. at the 6 hour there was a change in the cervix given misoprostol. The average cervical ripening with misoprostol was higher or greater than oxytocin which was $3.0323 \pm 1.47159$ compared with $0.7419 \pm 1.365$. The difference was also seen in 24 hours administration. The average cervical ripening with misoprostol was higher or greater than that of oxytocin which was $7.0968 \pm 2.11904$ compared to $2.5806 \pm 3.36427$. Statistically this difference is significant with $p<0.05$.

In this study parity is one of the characteristics that does not cause biased. Based on these characteristics, the success of cervical ripening in oxytocin administration appears to occur in 3rd and 4th parity, whereas in misoprostol the success of cervical ripening occurs in 1st parity to 4th parity. Parity is also a factor influencing the success of cervical ripening. Women who have given birth have higher nitric oxide compared to women who have never given birth (nullipara). Nitric Oxide (NO) can activate MMPs that affect cervical maturation.7 Nitric oxide affects cervical ripening and acts as a mediator of inflammation, regulates the activation of MMP that responsible for collagen degeneration and induces prostaglandin production by stimulating cyclooxygenation activation.

Oxytocin and prostaglandins are most often used cervical ripening pharmacological agents. Labor induction success is strongly influenced by ripening of the cervix. Labor 


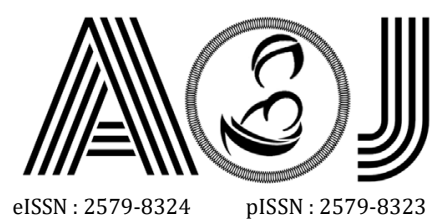

eISSN : 2579-8324
pISSN : 2579-8323

Ruang Redaksi Andalas Obstetrics and Gynecology Journal, Lantai 3 PPDS Obstetri dan Ginekologi Universitas Andalas, RSUP DR. M. Djamil Padang, Jl. Perintis Kemerdekaan Padang, Sumatera Barat 25127

induction failure rate high in an immature cervix and administration of prostaglandins has the advantage to ripening the cervix as well as the initiator of uterine contractions so the success rate is high. Preparations prostaglandins that are often used are misoprostol because it has advantages ie cheap, stable at room temperature and the preparation is easy. ${ }^{5}$

The dose of misoprostol given is low dosage with $25 \mu \mathrm{g}$, use dosage the safest is given without reducing the effect of misoprostol on cervical maturation. Although some research has found that a dose of $50 \mu \mathrm{g}$ is more effective at cervix ripening. Oxytocin used with drip did not make a meaningful change to cervix. In this study the numbers seemed high failure of cervical ripening, which is 22 patients compared with 9 patients.

Based on this research it is proven that misoprostol works on an immature cervix so that it can cause cervical changes, causing uterine contractions until vaginal delivery is achieved. With misoprostol, the delivery time will be shorter, which is less than 24 hours, and also reduces the number of cesarean sections caused by induction failure.

The results of this study indicate that the hypothesis is correct, that there are differences in the effects of misoprostol and oxytocin as cervical ripening agent. Misoprostol also shows a better cervical ripening effect compared to oxytocin.

\section{CONCLUSION}

Misoprostol is a better cervical ripening agent than oxytocin. Oxytocin should be given to a mature cervix. Using misoprostol as a cervical ripening agent can reduce the number of cesarean section due to failure of induction, reduce the length of treatment and reduce treatment costs.

\section{REFERENCES}

1. ACOG. Clinical Management Guideline for Obstetrian-Gynecologist. Vol 114. No 2. 2009.

2. Cunningham. Labor induction. Ed 23th. Mc graw Hill Companies. New York. 2010.

3. Serudji. Prediksi hasil induksi persalinan dengan drip oksitosin berdasarkan tes rangsangan papilla mamae. Skripsi. Padang. 1993.

4. Tenore Josie. Metods for Cervical Ripening and induction of Labour. American Family Physical. Number 10. 2003.

5. Ramos. Induction of labor. Obstetrics and gynecology clinics of north America. 32. 2005.

6. Arias. Pharmacology of oxytocin and Prostaglandin. In Clinical obstetrics and gynecology. Volume 43. Lippincott Williams and wilkins inc.Philadelphia. 2000.

7. Tommiska M.V. Nitric Oxide in Human Uterine Cervix: Role in Cervical. 2006. 